more likely reflects the differing sensitivities and modes of fault zone sampling of scattered-wave migration and polarizationtravel-time analysis. Extensive fault-parallel cracking at seismogenic depths could provide a high-permeability channel for alongfault fluid flow $(15,26)$.

The observed correlations of scattering potential, aftershock distribution, and coseismic slip imply that structure places a strong control on rupture over length scales much greater than event slip and thus at scales that should evolve slowly with respect to the earthquake cycle. This observation is favorable to the notion of repeatable events, but only inasmuch as the pattern of slip variability along individual fault segments is concerned. Scattering potential provides no clear indication of the initiation or termination of rupture; that is, there is no characteristic property of scattering that delimits rupture, only a correspondence between scattering and rupture where rupture has occurred. Lastly, the correlation of aftershock density with structural heterogeneity measured before rupture suggests that main shock-induced changes affecting aftershock production are structurally related or of second-order importance. Insofar as they affect scattering, KCM images made from recordings since the Landers sequence should reveal them.

\section{REFERENCES AND NOTES}

1. R. H. Sibson, in Earthquake Source Mechanics, S Das, J. Boatwright, C. Scholz, Eds. (Geophysical Monograph 37, American Geophysical Union, Washington, DC, 1986), pp. 157-168; G. King and J. Nábĕlek, Science 228, 984 (1985).

2. A. J. Michael and D. Eberhart-Phillips, Science 253, 651 (1991); C. Nicholson and J. M. Lees, Geophys. Res. Lett. 19, 1 (1992); J. M. Lees and C. Nicholson, Geology 21, 387 (1993); W. Foxall, A. Michelini, T. V. McEvilly, J. Geophys. Res. 98, 17691 (1993); D. Zhao and H. Kanamori, Geophys. Res. Lett. 20, 1083 (1993); ibid. 22, 763 (1995).

3. J. Revenaugh, Geophys. Res. Lett. 22, 543 (1995); Science 268, 1888 (1995).

4. K. Sieh et al., Science 260, 171 (1993)

5. In general, seismic energy is scattered by lateral variations in velocity and density over length scales comparable to, or shorter than, seismic wavelength. To quantify scattering, I use a significance scale (scattering potential), rather than absolute strength of scattering, because of the difficulty of accurately modeling amplitudes of high-frequency crustal waves. Tests performed with synthetic data sets demonstrate a monotonic, but nonlinear, mapping of scattering strength to significance.

6. This pattern is partly a result of the limited ray-parameter coverage afforded by teleseismic events, which, coupled with frequency band constraints $(\sim 0.1$ to 1 $\mathrm{Hz}$ ), renders $\mathrm{KCM}$ unable to image the narrow (10 to $200 \mathrm{~m}$ ), near-vertical, low-velocity fault zones that often characterize the structural expression of faulting at shallow depths $(<5$ to $10 \mathrm{~km})$ W. D. Mooney and A. Ginzburg, Pure Appl. Geophys. 124, 141 (1986); Y.-G. Li, K. Aki, D. Adams, A. Hasemi, W. H. K. Lee, J. Geophys. Res. 99, 11705 (1994)].

7. Length scale is quoted as semivariogram offset at $80 \%$ of variance. Active fault density is defined as total mapped fault length resolved on the scattering grid $\left(0.01^{\circ}\right.$ by $\left.0.01^{\circ}\right)$. Seismic measures of the length scale of heterogeneity, based on $P$-wave coda duration and amplitude, yield comparable estimates [C. A Powell and A. S. Meltzer, Geophys. Res. Lett. 11, 481
(1984); A. Frankel and R. W. Clayton, J. Geophys. Res. 91, 6465 (1986); see also (2)].

8. The nominal significance of this correlation exceeds $99.99 \%$ on the assumption that all samples are independent. The assumption of an 8-km correlation length scale (7) results in a conservative estimate of 99.5\% significance.

9. R. Wu and K. Aki, Geophysics 50, 582 (1985).

10. Scattering vanishes along strike and normal to a single crack (W. M. Visscher, J. Acoust. Soc. Am. 69,50 (1981)]. Scattering from a cracked volume is complex and need not vanish entirely [R. L. Gibson and A. Ben-Menahem, J. Geophys. Res. 96, 19905 (1991)].

11. Angles are expressed as the minimum of trend to strike and trend to fault normal; the maximum is $45^{\circ}$

12. E. Hauksson, L. M. Jones, K. Hutton, D. EberhartPhillips, J. Geophys. Res. 98, 19835 (1993).

13. R. C. Aster and P. M. Shearer, Geophys. J. Int. 108, 740 (1992); H. Kern and H.-R. Wenk, J. Geophys. Res. 95, 11213 (1990)

14. T. Jones and A. Nur, Geology 10, 260 (1982)

15. S. Crampin, R. Evans, B. K. Atkinson, Geophys. J. R. Astron. Soc. 76, 147 (1984)

16. E. Hauksson, Bull. Seismol. Soc. Am. 84, 917 (1994).
17. S. Kaneshima, J. Geophys. Res. 95, 11121 (1990).

18. P. C. Leary, Y.-G. Li, K. Aki, Geophys. J. R. Astron. Soc. 91, 461 (1987); Z. Zhang and S. Y. Schwartz. J. Geophys. Res. 99, 9651 (1994).

19. T. Lay and H. Kanamori, in Earthquake Prediction, An International Review, D. Simpson and P. Richards, Eds. (Maurice Ewing Series 4, American Geophysical Union, Washington, DC, 1981), pp. 579592.

20. A. Jin and K. Aki, J. Geophys. Res. 94, 14041 (1989).

21. B. P. Cohee and G. C. Beroza, Bull. Seismol. Soc. Am. 84, 692 (1994).

22. Cross-fault scattering variance is measured as the variance of scattering within $20-\mathrm{km}$-wide by $2-\mathrm{km}$ long bins along the fault.

23. T. K. Rockwell et al., Eos 74, 67 (1993).

24. T. J. Sheppard, J. Geophys. Res. 95, 11115 (1990).

25. Y.-G. Li, T.-L. Teng, T. L. Henyey, Bull. Seismol. Soc. Am. 84, 307 (1994)

26. C. H. Scholz, The Mechanics of Earthquakes and Faulting (Cambridge Univ. Press, Cambridge, 1990).

27. Supported by NSF award EAR-9417493. Institute of Tectonics contribution 282

20 June 1995; accepted 25 September 1995

\title{
North Atlantic Deepwater Temperature Change During Late Pliocene and Late Quaternary Climatic Cycles
}

\author{
Gary S. Dwyer, ${ }^{\star}$ Thomas M. Cronin, Paul A. Baker, \\ Maureen E. Raymo, Jeffrey S. Buzas, Thierry Corrège $\dagger$
}

Variations in the ratio of magnesium to calcium $(\mathrm{Mg} / \mathrm{Ca})$ in fossil ostracodes from Deep Sea Drilling Project Site 607 in the deep North Atlantic show that the change in bottom water temperature during late Pliocene 41,000 -year obliquity cycles averaged $1.5^{\circ} \mathrm{C}$ between 3.2 and 2.8 million years ago $(\mathrm{Ma})$ and increased to $2.3^{\circ} \mathrm{C}$ between 2.8 and 2.3 $\mathrm{Ma}$, coincidentally with the intensification of Northern Hemisphere glaciation. During the last two 100,000-year glacial-to-interglacial climatic cycles of the Quaternary, bottom water temperatures changed by $4.5^{\circ} \mathrm{C}$. These results show that glacial deepwater cooling has intensified since $3.2 \mathrm{Ma}$, most likely as the result of progressively diminished deepwater production in the North Atlantic and of the greater influence of Antarctic bottom water in the North Atlantic during glacial periods. The ostracode $\mathrm{Mg} / \mathrm{Ca}$ data also allow the direct determination of the temperature component of the benthic foraminiferal oxygen isotope record from Site 607, as well as derivation of a hypothetical sea-level curve for the late Pliocene and late Quaternary. The effects of dissolution on the $\mathrm{Mg} / \mathrm{Ca}$ ratios of ostracode shells appear to have been minimal.

Deep-ocean circulation affects the storage and transfer of heat and nutrients in the ocean, as well as atmospheric $\mathrm{CO}_{2}(1-3)$.

G. S. Dwyer and P. A. Baker, Department of Geology, Duke University, Durham, NC 27708, USA

T. M. Cronin, U.S. Geological Survey, Branch of Paleontology and Stratigraphy, Mail Stop 970 National Center Reston, VA 22092, USA.

M. E. Raymo, Department of Earth, Atmospheric, and Planetary Sciences, Massachusetts Institute of Technology, Cambridge, MA 02139, USA.

J. S. Buzas, Department of Mathematics and Statistics, University of Vermont, Burlington, VT 05051, USA.

T. Corrège, Départment de Géologie et Océanographie, Université de Bordeaux I, Avenue des Facultés, Bordeaux, France.

"To whom correspondence should be addressed. †Present address: Laboratoire des Formations Superficielles, ORSTOM, 32 Avenue Henri Varagnat, 93143 Bondy Cedex, France.
Attempts to evaluate deep-ocean bottom water temperature (BWT) changes, which accompany climate-driven changes in deepocean circulation, have focused on the benthic foraminiferal oxygen isotope $\left(\delta^{18} \mathrm{O}\right)$ record, but results have been equivocal. Emiliani (4) first postulated that glacial-to-interglacial variations in the $\delta^{18} \mathrm{O}$ in benthic foraminifers reflected changes in both ice volume and BWT. Later, Shackleton (5) ascribed the $\delta^{18} \mathrm{O}$ variations mainly to changes in ice volume. Recognition of the differences in the $\delta^{18} \mathrm{O}$ records of various deep-sea cores and the discordance between sea-level records (6) and the $\delta^{18} \mathrm{O}$ record, however, led Chappell and Shackleton (7) to propose that deep Pacific glacial BWTs were $1^{\circ}$ to $1.5^{\circ} \mathrm{C}$, and possibly $2.5^{\circ} \mathrm{C}$, lower than interglacial tem- 
peratures. Labeyrie et al. (8), comparing the deep Norwegian Sea $\delta^{18} \mathrm{O}$ record to records from the Atlantic and Pacific Oceans, postulated that the world's deepwater temperatures were $0^{\circ}$ to $-1^{\circ} \mathrm{C}$ during the entire last glacial period (isotope stages 2 to 4 ), requiring a lowering of the deep-ocean temperature of $2^{\circ}$ to $3.5^{\circ} \mathrm{C}$. Mix and Pisias (9) rejected this idea on the basis of the results of heat budget modeling, because such dramatic cooling required an improbable (10) faster-than-present thermohaline turnover of the oceans during the last glacial period. Understanding of the uncertain contribution of BWT change to the benthic foraminiferal $\delta^{18} \mathrm{O}$ record and, more generally, to changes in oceanic circulation and heat budget during periods of climate

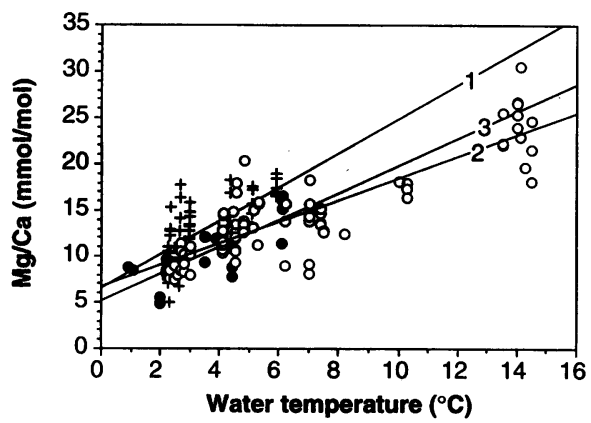

Fig. 1. Plot of $\mathrm{Mg} / \mathrm{Ca}$ ratio versus water temperature with least-squares fits of samples of core-top ostracodes from the genus Krithe. Each data point represents the analysis of a single Krithe valve. Plus signs are from (19); open circles are from this study. Also shown for comparison are electron microprobe data on Krithe from an earlier study (solid circles) (18). Summaries for each of the three regression lines follow, where $a$ and $b$ represent the least-squares estimates for intercept and slope, respectively (standard errors are in parentheses). Line 1 (19): $a=$ 6.430 (0.930), $b=1.923$ (0.254); line 2 (this study): $a$ $=6.729(0.547), b=1.71(0.072) ;$ and line $3(18): a$ $=5.158$ (1.099), $b=1.466(0.272)$.

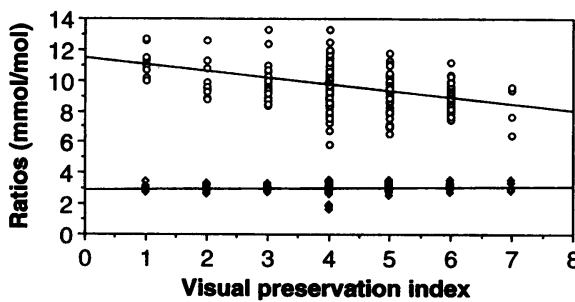

Fig. 2. Ostracode VPI plotted versus $\mathrm{Mg} / \mathrm{Ca}$ (upper line) and $\mathrm{Sr} / \mathrm{Ca}$ (lower line) ratios in Pliocene and Quaternary Krithe shells from DSDP Site 607 and Chain 82-24-4PC. VPI was determined by binocular microscopic examination of the ostracode shells. A lower VPI value indicates a better preserved (more translucent) shell; for example, 1 = transparent, $4=$ translucent, and $7=$ opaque white. Summaries for each regression line follow, where $a$ and $b$ represent the least-squares estimates for intercept and slope, respectively (standard errors are in parentheses). $\mathrm{Mg} / \mathrm{Ca}$ line: $a=$ $11.409(0.232), b=-0.415(0.053) ;$ Sr/Ca line: $a=$ $2.934(0.098), b=0.025(0.023)$. change requires a more precise method of measuring bottom water paleotemperature.

Here we use the $\mathrm{Mg} / \mathrm{Ca}$ ratio of shells of the deep-sea ostracode genus Krithe to infer BWT in the deep North Atlantic Ocean during late Pliocene and late Quaternary climatic cycles. Ostracodes are bivalved Crustacea whose shells are increasingly being used for trace element and isotopic studies of nonmarine $(11,12)$ and marine $(13$,
14) paleoenvironments. Their shells are made of calcite $\left(\mathrm{CaCO}_{3}\right)$ containing minor amounts of coprecipitated magnesium. The amount of coprecipitated magnesium can be described by the following relation: $(\mathrm{Mg} /$ $\mathrm{Ca})_{\text {cal }}=D(\mathrm{Mg} / \mathrm{Ca})_{\text {sol }}$; where $(\mathrm{Mg} / \mathrm{Ca})_{\text {cal }}$ is the molar ratio of $\mathrm{Mg}$ to $\mathrm{Ca}$ in calcite, $D$ is the $\mathrm{Mg}$ distribution coefficient, and $(\mathrm{Mg} /$ $\mathrm{Ca})_{\text {sol }}$ is the molar ratio of $\mathrm{Mg}$ to $\mathrm{Ca}$ in the ambient solution (in this case, seawater).

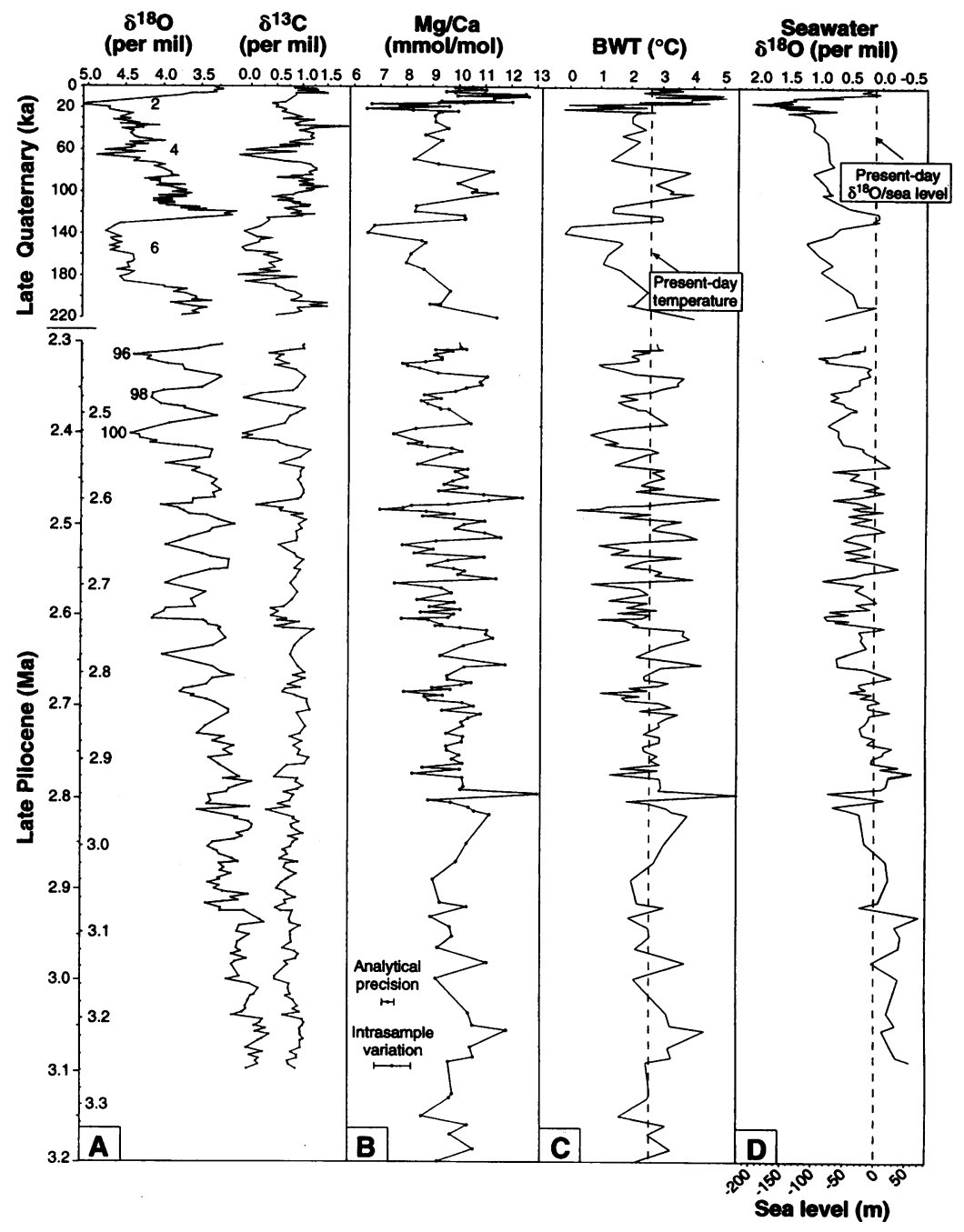

Fig. 3. (A) Benthic foraminiferal oxygen and carbon stable isotopic record for Site 607 [late Pliocene, from (21) and (23)] and for Chain 84-24-4PC [late Quaternary, from (2); ka, thousand years ago]. All analyses are for Cibicidoides wuellerstorfi. To correct for the well-known disequilibrium effect in C. wuellerstorfi, 0.64 per mil was added to the measured $\delta^{18} \mathrm{O}$ values. Glacial oxygen isotope stages are displayed along the $\delta^{18} \mathrm{O}$ curve. (B) Ostracode $\mathrm{Mg} / \mathrm{Ca}$ ratio and (C) $\mathrm{Mg} / \mathrm{Ca}$-based paleo-BWT calculated with the use of calibration 2 (solid line). About half of the data points represent the $\mathrm{Mg} / \mathrm{Ca}$ ratio determined on a single adult valve of ostracode genus Krithe, and about half of the data points represent the mean value of two to five single-valve analyses from the same stratigraphic interval. These multiple-specimen intervals had an average standard deviation of $6 \%$, which is about three times the analytical precision of $\mathrm{Mg} / \mathrm{Ca}$ ratio measurement. BWT was calculated as discussed in the text. (D) The solid line is the reconstructed $\delta^{18} \mathrm{O}$ of seawater at this site, calculated with the use of our BWT values, the benthic foraminiferal $\delta^{18} \mathrm{O}$ values, and the calcite-water $\delta^{18} \mathrm{O}$ equilibrium equation from (36). The curve also represents a reconstruction of sea level relative to that of today, which was calculated with the assumption that a 0.1 per mil shift in seawater $\delta^{18} \mathrm{O}$ results from a $10-\mathrm{m}$ change in sea level (37). Modern bottom water values at this site are: in situ temperature, $2.6^{\circ} \mathrm{C}(47)$; salinity, 34.9 per mil $(47) ; \delta^{13} \mathrm{C}$ of dissolved inorganic carbon, 0.9 per mil (PDB) (23); and $\delta^{18} \mathrm{O}, 0.1$ per mil (SMOW) (48). The present-day sea-level datum is positioned at 0.1 per mil. Pliocene ages discussed in the text are from the left-hand Pliocene time scale $(21,23)$; the right-hand Pliocene time scale is from (43). 
Because of the long oceanic residence times for $\mathrm{Ca}$ and $\mathrm{Mg}$, which are on the order of $10^{6}$ and $10^{7}$ years, respectively (15), we assume that the $\mathrm{Mg} / \mathrm{Ca}$ ratio of seawater is constant over several million years, which implies that the $\mathrm{Mg} / \mathrm{Ca}$ ratio of marine calcite is solely controlled by $D$.

A strong temperature dependence of $D$ is well known for inorganic calcite precipitated experimentally from seawater (16). For biologically precipitated calcite, Chave (17) showed that $\mathrm{Mg}$ content is also controlled by phylogeny. Studies of ostracodes $(11,14,18)$

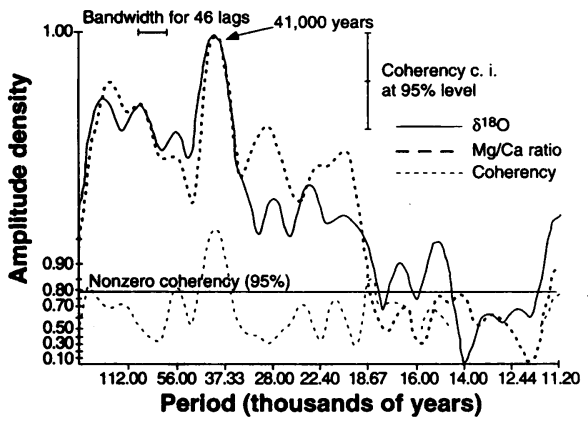

Fig. 4. Results of cross-spectral analysis between benthic foraminiferal $\delta^{18} \mathrm{O}$ and ostracode $\mathrm{Mg} / \mathrm{Ca}$ ratio records for the late Pliocene interval from 3.0 to 2.3 Ma. Spectra were generated after interpolation of data to equal time intervals. The $80 \%$ confidence interval (c. i.) and bandwidth are shown at the top of the figure and a statistical summary of coherency and phase lags is given in Table 1. See Imbrie et al. (32) for further discussion of methodology.

Table 1. Statistical summary of cross-spectral time series analyses. Maximum variance is between 40,000 and 41,000 years. The coherency $(k)$ and phase angle $(f)$ are significant at the 0.20 level. Sampling interval is 5600 years from 2.31 to 3.07 $\mathrm{Ma}$. The phase of variables was calculated versus negative $\delta^{18} \mathrm{O}$ (or maximum interglaciation). Negative phases indicate that these variables lead $\delta^{18} \mathrm{O}$.

\begin{tabular}{lcrc}
\hline $\begin{array}{l}\text { Vari- } \\
\text { able }\end{array}$ & $k$ & $f$ (degrees) & $\begin{array}{r}\text { Lead time } \\
\text { (thousands } \\
\text { of years) }\end{array}$ \\
\hline $\mathbf{\delta}^{13} \mathrm{C}$ & 0.93 & $-3.0 \pm 17$ & $0.3 \pm 1.9$ \\
$\mathrm{Mg} / \mathrm{Ca}$ & 0.96 & $-32.2 \pm 13$ & $3.6 \pm 1.4$ \\
\hline
\end{tabular}

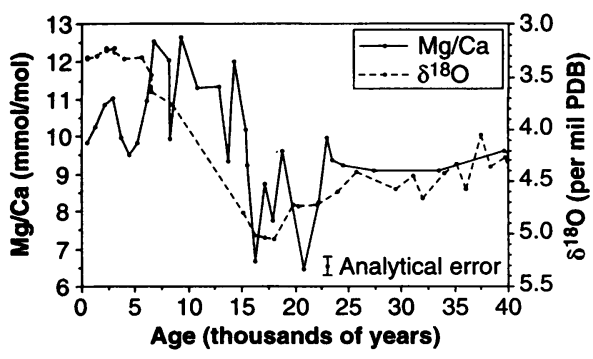

Fig. 5. Expanded section of Fig. 3, showing past 40,000-year record of ostracode $\mathrm{Mg} / \mathrm{Ca}$ ratios and benthic foraminiferal $\delta^{18} \mathrm{O}$. have demonstrated both ontogenetic and intergeneric variation of $D$, which requires empirical calibration of BWT and $(\mathrm{Mg} / \mathrm{Ca})_{\mathrm{cal}}$ if different genera are studied. Using modern adult ostracodes from sediment core tops collected from the Coral Sea at BWTs ranging from $2^{\circ}$ to $6^{\circ} \mathrm{C}$, Corrège et al. (19) derived the following empirical relation for the genus Krithe: BWT $\left({ }^{\circ} \mathrm{C}\right)=(0.520 \times$ $\mathrm{Mg} / \mathrm{Ca}$ ) - 3.3, where $\mathrm{Mg} / \mathrm{Ca}$ is in millimoles per mole (calibration 1, Fig. 1). In a similar fashion, using core-top Krithe from the North Atlantic collected over a wider temperature range $\left(2^{\circ}\right.$ to $\left.14^{\circ} \mathrm{C}\right)$, we determined a calibration for Krithe to be BWT $\left({ }^{\circ} \mathrm{C}\right)=(0.854 \times$ $\mathrm{Mg} / \mathrm{Ca}$ ) -5.75 (calibration 2, Fig. 1). The error in predicting temperature from the fossil specimens we analyzed was $\pm 1^{\circ} \mathrm{C}(20)$.

Using calibration 2, which was selected for several reasons (20), we calculated BWTs from the $\mathrm{Mg} / \mathrm{Ca}$ ratio of Krithe shells from the deep North Atlantic for the late Pliocene interval from 3.2 to $2.3 \mathrm{Ma}$ from Deep Sea Drilling Project (DSDP) Site $607\left(41^{\circ} \mathrm{N}\right.$, $33^{\circ} \mathrm{W}$; water depth, $3427 \mathrm{~m}$ ) and from the late Quaternary interval from 200,000 years ago to the present from Chain core 82-24-4PC $\left(42^{\circ} \mathrm{N}, 33^{\circ} \mathrm{W}\right.$; water depth, $\left.3427 \mathrm{~m}\right)$. We chose these cores for several reasons. Continuous high-resolution benthic stable isotope data have been collected for both DSDP Site 607 (21) and Chain 82-24-4PC (2, 22). In this region of the North Atlantic, deep-ocean temperature changes during glacial-to-interglacial fluctuations are thought to have been caused by changes in the relative contributions of warm, nutrient-poor, North Atlantic deep water (NADW), which today predominates at the site, and of colder, nutrient-rich, Antarctic bottom water (AABW), which is hypothesized to have been more important during glacial stages $(2,23,24)$. Selection of this site enabled us to compare the magnitude of BWT changes during three distinct climatic states: a relatively warm interval of global climate having low-amplitude climatic cycles [3.2 to $2.8 \mathrm{Ma}(25-27)$ ], the transition to cooler global climate and high-amplitude 41,000-year cycles [2.8 to $2.3 \mathrm{Ma}$, isotope stages 110 to $95(21,25)]$, and the last two 100,000 -year cycles of the Quaternary (isotope stages 7 to 1$)$. Finally, the ostracode taxonomy at Site 607 is well known (28), and quantitative analyses of ostracode assemblages from the interval from 3.2 to $2.3 \mathrm{Ma}$ reveal that there are four water-mass-related assemblages representing glacial, deglacial, peak interglacial, and early glacial environments, which vary in relative abundances at the 41,000 -year obliquity cycles that are characteristic of this portion of the $\delta^{18} \mathrm{O}$ record (29).

We carried out $\mathrm{Mg}$ and $\mathrm{Ca}$ analyses on individual adult valves of Krithe using the procedures in (30), which included ranking each specimen with a visual preservation index (VPI). A weak correlation between ostracode VPI and $\mathrm{Mg} / \mathrm{Ca}$ ratio and the large range of $\mathrm{Mg} / \mathrm{Ca}$ ratios at a single VPI value in the Pliocene and Quaternary material we studied (Fig. 2) suggested that postmortem alteration of the shell (dissolution) had little effect on the $\mathrm{Mg} / \mathrm{Ca}$ ratio in Krithe shells (31). However, because BWT and bottom water corrosiveness likely covary over time at Site 607 , it is difficult to completely rule out the effect of selective preservation on $\mathrm{Mg} / \mathrm{Ca}$ variation. Analyses of 10 Krithe species from Site 607 and Chain 82-24-4PC indicated no substantial interspecific variation in the $\mathrm{Mg} / \mathrm{Ca}$ ratio.

In general, there is a good correspondence between the ostracode $\mathrm{Mg} / \mathrm{Ca}$ ratios and foraminiferal stable isotope records from the cores (Fig. 3). $\mathrm{Mg} / \mathrm{Ca}$ ratios increase during interglacial stages and decrease during glacial stages. In the longer Pliocene section, variance of $\mathrm{Mg} / \mathrm{Ca}$ ratios at the 41,000-year periodicity is coherent with that observed in the isotopic records (Fig. 4 and Table 1). However, the $\mathrm{Mg} / \mathrm{Ca}$ record is not in phase with the benthic isotope records; maxima in Krithe $\mathrm{Mg} / \mathrm{Ca}$ ratios lead maxima in $\delta^{13} \mathrm{C}$ and minima in $\delta^{18} \mathrm{O}$ by about 3500 years. The $\mathrm{Mg} / \mathrm{Ca}$ record is in phase (at the 41,000-year periodicity) with maximum abundance of the Argilloecia-Cytheropteron ostracode assemblage, which predominates during late deglacial-early interglacial times (29). The phase relations summarized in Table 1 imply that changes in deep-ocean temperature (indicated by $\mathrm{Mg} / \mathrm{Ca}$ ratios) lead changes in ice volume (indicated by $\delta^{18} \mathrm{O}$ ) and also changes in deep-ocean ventilation (indicated by $\delta^{13} \mathrm{C}$ ) at this site, thus placing ostracode $\mathrm{Mg} / \mathrm{Ca}$ variations in the "early response" group of Imbrie et al. (32). This result suggests that cooling of northern source water (NADW) occurred before the increased influence of southern source water $(\mathrm{AABW})$ at Site 607.

During the relatively warm and stable climatic interval from 3.2 to $2.8 \mathrm{Ma}(33,34)$, $\mathrm{Mg} / \mathrm{Ca}$ ratios averaged $10.0 \mathrm{mmol} / \mathrm{mol}$ (indicating a temperature of $2.7^{\circ} \mathrm{C}$ ) and ranged from $8.8 \mathrm{mmol} / \mathrm{mol}\left(1.6^{\circ} \mathrm{C}\right)$ to $12.0 \mathrm{mmol} / \mathrm{mol}$ $\left(4.5^{\circ} \mathrm{C}\right)$. The average glacial-to-interglacial change (peak-to-trough shift) in $\mathrm{Mg} / \mathrm{Ca}$ during this interval was about $1.7 \mathrm{mmol} / \mathrm{mol}$ (a temperature change of $1.5^{\circ} \mathrm{C}$ ). During the interval from 2.8 to $2.3 \mathrm{Ma}$, when continental glaciation in the Northern Hemisphere intensified, the average glacial-to-interglacial shift in $\mathrm{Mg} / \mathrm{Ca}$ increased to $2.2 \mathrm{mmol} / \mathrm{mol}$; a temperature change of $2.3^{\circ} \mathrm{C}$. Glacial $\mathrm{Mg} / \mathrm{Ca}$ values averaged $8.4 \mathrm{mmol} / \mathrm{mol}\left(1.3^{\circ} \mathrm{C}\right)$ and interglacial peak values averaged $11.1 \mathrm{mmol} /$ mol $\left(3.6^{\circ} \mathrm{C}\right)$. The absolute glacial minimum and interglacial maximum $\mathrm{Mg} / \mathrm{Ca}$ values for this period were 7.02 and $12.47 \mathrm{mmol} / \mathrm{mol}$, which equate to $0.0^{\circ}$ and $4.9^{\circ} \mathrm{C}$, respectively.

In the late Quaternary record, glacial-tointerglacial changes in $\mathrm{Mg} / \mathrm{Ca}$ ratios are large, about $5 \mathrm{mmol} / \mathrm{mol}$ between isotope 
stages 7 and 6 and between stages 6 and 5 , and about $6 \mathrm{mmol} / \mathrm{mol}$ from the last glacial maximum to the mid-Holocene (Figs. 3B and 5). These shifts equate to BWT changes of $4^{\circ}$ and $5^{\circ} \mathrm{C}$, respectively. Interglacial $\mathrm{Mg} /$ Ca values (stages 7, 5, and 1) are similar to those of the late Pliocene interglacial stages, with an absolute maximum of $12.7 \mathrm{mmol} /$ mol $\left(5.1^{\circ} \mathrm{C}\right)$ in the mid-Holocene. Glacial $\mathrm{Mg} / \mathrm{Ca}$ values are the lowest observed, decreasing to about $6.5 \mathrm{mmol} / \mathrm{mol}\left(0^{\circ} \mathrm{C}\right)$ during oxygen isotope stages 6 and 2 . The $\mathrm{Mg} /$ $\mathrm{Ca}$ record varies considerably during late glacial stage 2 and through the Holocene (Fig. 5), which may suggest short-term variations in thermohaline circulation (35). The record shows also that BWTs have dropped by $1^{\circ}$ to $2^{\circ} \mathrm{C}$ since the mid-Holocene.

The ostracode BWT estimates provide a means for isolating the temperature contribution from the benthic foraminiferal $\delta^{18} \mathrm{O}$ record and for reconstructing a seawater $\delta^{18} \mathrm{O}$ curve (Fig. 3D). To illustrate this, we used the $\mathrm{Mg} / \mathrm{Ca}$-based temperatures and the following equation: $\delta^{18} \mathrm{O}_{\text {cal }}$ (PDB) $=$ $\delta^{18} \mathrm{O}_{\text {sw }}$ (SMOw) $+(2.78)\left(10^{6}\right)\left(T^{-2}\right)$ 33.3557, where PDB is Pee Dee belemnite standard, SMOW is standard mean ocean water, temperature is in degrees kelvin, and $\delta^{18} \mathrm{O}_{s w}$ is the oxygen isotopic composition of seawater (36). We assume that variations in $\delta^{18} \mathrm{O}_{\mathrm{sw}}$ represent changes in glacial ice volume $(9)$ and that $10 \mathrm{~m}$ of sea-level change results in a 0.1 per mil change in $\delta^{18} \mathrm{O}_{\text {sw }}$ (37). The Mg/Ca-based paleo-sealevel record is in general agreement with independent sea-level estimates for the late Pliocene and the late Quaternary. The high eustatic sea-level estimates for the period from 3.2 to $2.8 \mathrm{Ma}$ (Fig. 3D) are reasonably close to the 25 - to $40-\mathrm{m}$ values estimated from the passive continental margin of the eastern United States $(34,38)$. Moreover, the $\mathrm{Mg} / \mathrm{Ca}$-based sea-level record indicates that the sea level fluctuated on average 60 to $70 \mathrm{~m}$ during the climatic cycles between 2.8 and $2.3 \mathrm{Ma}$, which is quite similar to the 40- to 60-m drops in sea level estimated for this period from ocean margin sequences on the coast of the Sea of Japan (39). Likewise, in the late Quaternary, the glacial-to-interglacial sea-level changes of 120 and $150 \mathrm{~m}$ for the transitions from stage 6 to 5 and from stage 2 to 1 , respectively, show firstorder correspondence to the sea-level estimates, based on coral reef studies (40).

Interpretation of these data should be considered with caution because, although its effects appear to be minimal, dissolution may play a role in altering the $\mathrm{Mg} / \mathrm{Ca}$ ratio of ostracode shells. The BWT estimates we derived appear to be reasonable; absolute values of BWT calculated are comparable to modern values for NADW at this site and for AABW from a similar depth in the South Atlantic (41). Between 2.8 and $2.3 \mathrm{Ma}$, the lowest calculated glacial BWT was around $0^{\circ} \mathrm{C}$, and the mean glacial temperature was around $1^{\circ} \mathrm{C}$. Today, AABW is about $1^{\circ}$ to $2^{\circ} \mathrm{C}$ colder than NADW at comparable depths in the southern ocean; thus, these temperature estimates suggest that $\mathrm{AABW}$ began influencing the region at this time, and they support evidence from deepwater $\delta^{13} \mathrm{C}$ gradients for stronger AABW during these glacial periods (23). Similarly, the BWT of $0^{\circ}$ to $1.5^{\circ} \mathrm{C}$ calculated for the last glacial period, and the subsequent warming of around $3^{\circ} \mathrm{C}$ into the Holocene, are in good agreement with two recent dynamic ocean modeling studies that predict a weakening and shallowing of the North Atlantic thermohaline circulation cell during glacial climatic conditions and, consequently, a northward incursion of $\mathrm{AABW}$ resulting in water temperatures in the deep North Atlantic that are $1^{\circ}$ to $3^{\circ} \mathrm{C}$ lower than those of today (42). Further, the increasing amplitude of glacial-to-interglacial BWT change from 3.2 to $2.3 \mathrm{Ma}$ and in the late Quaternary reflects a pattern that is anticipated by many other proxy indicators of climate, such as isotopes and sea-surface temperatures (SSTs). Lastly, the relatively stable BWTs from 3.2 to 2.8 Ma would be predicted if, as postulated (23), NADW dominated Site 607 before 2.8 $\mathrm{Ma}$ and $\mathrm{AABW}$ influence was minimal. Sustained NADW flow is also expected from marine microfaunal data indicating enhanced Gulf Stream flow during this time interval $(26,33,43,44)$. The similarity of BWTs calculated for this interval to those of today suggests that late Pliocene SSTs in the area of NADW formation were, with few exceptions, comparable to those today.

This study demonstrates the potential application of $\mathrm{Mg} / \mathrm{Ca}$ ratios found in ostracodes for assessment of ocean paleotemperature, interpretation of the deep-sea isotope record, construction of independent sea-level curves, and improvement in our understanding of deep oceanic circulation, high-latitude SST, and climate change.

\section{REFERENCES AND NOTES}

1. W. S. Broecker et al., Nature 315, 21 (1985)

2. E. A. Boyle and L. D. Keigwin, Earth Planet. Sci. Lett. 76, 135 (1985)

3. A. C. Mix and R. G. Fairbanks, ibid. 73, 231 (1985); E. A. Boyle, Science 249, 863 (1991); L. D. Keigwin et al., J. Geophys. Res. 96, 16811 (1991).

4. C. Emiliani, J. Geol. 63,538 (1955).

5. N. J. Shackleton, Nature 215, $15(1967)$

6. T. M. Cronin, Mar. Micropaleontol. 8, 89 (1983).

7. J. Chappell and N. J. Shackleton, Nature 324, 137 (1986).

8. L. D. Labeyrie et al. , ibid. 327, 477 (1987)

9. A. C. Mix and N. G. Pisias, ibid. 331, 249 (1988)

10. W. S. Broecker et al., Paleoceanography 3, 1 (1988); N. J. Shackleton et al. , Nature 335, 708 (1988).

11. A. R. Chivas et al., Palaeogeogr. Palaeoclimatol. Palaeoecol. 54, 43 (1986).

12. A. R. Chivas et al., in Continental /sotopic Indicators of Climate, P. K. Swart et al., Eds. (American Geophysical Union, Washington, DC, 1993), pp. 113121; D. A. Hodell et al., Nature 352, 790 (1991).

13. P. De Deckker et al., Palaeogeogr. Palaeoclimatol.
Palaeoecol. 66, 231 (1988).

14. T. Corrège, Ocean Drill. Prog. Proc. Sci. Results 133 175 (1993).

15. R. Chester, Marine Geochemistry (Unwin Hyman, London, 1990).

16. E. A. Burton and L. M. Walter, Geochim. Cosmochim. Acta 55, 777 (1991).

17. K. E. Chave, J. Geol. 62, 266 (1954).

18. H. M. Cadot and R. L. Kaesler, Univ. Kansas Paleontol. Contrib. 87, 1 (1977).

19. T. Corrège, P. De Deckker, J. M. G. Shelley, A. R Chivas, in preparation.

20. The errors for predicting temperature from $\mathrm{Mg} / \mathrm{Ca}$ ratios of fossil Krithe shells with a $95 \%$ confidence interval are $0.9^{\circ}$ and $1.3^{\circ} \mathrm{C}$ for calibrations 1 and 2 , respectively. The calculated error results from consideration of the variability of the $\mathrm{Mg} / \mathrm{Ca}$ values in the core-top calibration data set and the fossil specimens, and it accounts for the observation that the intrasample variability of fossil Krithe is substantially less than the variability in core-top specimens. Furthermore, the erro estimate is for a temperature prediction based on the $\mathrm{Mg} / \mathrm{Ca}$ ratio of a single ostracode specimen. The error can be reduced by a factor of $1 / n^{1 / 2}$ if the mean $\mathrm{Mg} / \mathrm{Ca}$ ratio of several specimens is used to predict temperature, where $n$ is the number of ostracodes used to calculate the mean. For example, at Site 607 and Chain 82-24-4PC, the prediction error when calibration 2 is used is reduced to $1^{\circ} \mathrm{C}$ when the mean $\mathrm{Mg} / \mathrm{Ca}$ ratio of three ostracodes is used to predict $\sim$ temperature. This error is approximately five times the instrumental precision on $\mathrm{Mg} / \mathrm{Ca}$ ratio measurement. (广) Calibration 2 is used to calculate BWTs because it is the most comprehensive and because it was constructed under the same analytical conditions as the fossil material. The differences in slope, absolute val- 1 ues, and amount of scatter between the three calibrations may result from interlaboratory bias or from differences in the natural variability of the core-top sites in the three studies. About one-half of the fossil Krithe specimens analyzed resulted in BWT estimates of less than $2^{\circ} \mathrm{C}$, which is outside the range of the calibration. These BWT estimates are valid provided that the relation between $\mathrm{Mg} / \mathrm{Ca}$ and temperature remains linear below $2^{\circ} \mathrm{C}$.

21. M. E. Raymo et al., Paleoceanography 4, 413 (1989)

22. T. L. Ku et al., Deep-Sea Res. 19, 233 (1972).

23. M. E. Raymo, D. Hodell, E. Jansen, Paleoceanography 7, 645 (1992)

24. D. W. Lea and E. A. Boyle, Nature 347, 269 (1989)

25. M. E. Raymo, in Start of a Glacial, NATO ASI Series 13, G. J. Kukla and E. Went, Eds. (Springer-Verlag, New York, 1992), pp. 207-223.

26. H. J. Dowsett et al., Science 258, 1133 (1992).

27. N. J. Shackleton et al., in Ocean Drill. Prog. Proc. Sci. Results 138, 337 (1995)

28. R. C. Whatley and G. P. Coles, Rev. Esp. Micropaleontol. 19, 33 (1987).

29. T. M. Cronin, Proceedings of the ODP Conference on Marine Biosphere, in press; H. J. Dowsett, K. D. Kyle, in preparation.

30. Sediment samples $\left(10 \mathrm{~cm}^{3}\right)$ were soaked in deionized water and rinsed in tap or deionized water. Ostracodes were brush-picked from the $\geq 150$ - $\mu \mathrm{m}$ fraction sediment and cleaned with ethanol or Clorox. Species of Krithe were identified with the use of the taxonomy of Coles et al. (45). On the basis of microscopic inspection, individual valves were then assigned a VP ranging from 1 (transparent) to 7 (opaque white). Most specimens ranked between 3 and 5 . Each valve was sonicated in a two-step bath of deionized water and dissolved in 4 to $30 \mathrm{ml}$ of $0.05 \mathrm{~N}$ nitric acid, depending on valve weight. For most samples, $\mathrm{Ca}$ and $\mathrm{Mg}$ were analyzed simultaneously on a Spectraspan 7 direct current plasma (DCP) atomic emission spectrometer at the Duke University Department of Geology. About 60 of the specimens (samples from 2.45 to $2.3 \mathrm{Ma}$ ) were analyzed by atomic absorption (AA) on a PerkinElmer 5000 AA spectrophotometer; Ca was analyzed by flame and $\mathrm{Mg}$ was analyzed by graphite fumace (also at Duke). Matrix-matched instrument-calibration standards were mixed from pure, plasma-grade standard solutions. Analytical precision for $\mathrm{Ca}$ and $\mathrm{Mg}$, based on replicate analysis of samples and standards, is $\pm 3 \%$ for DCP and $\pm 5 \%$ for AA. Repeated analysis of an in-house limestone standard $(n=40)$ 
yielded $\mathrm{Mg} / \mathrm{Ca}$ of $8.50 \mathrm{mmol} / \mathrm{mol} \pm 0.04(1 \sigma)$ for $\mathrm{DCP}$ and $8.10 \mathrm{mmol} / \mathrm{mol} \pm 0.2(1 \sigma)$ for $\mathrm{AA}$. To normalize the two data sets, $0.40 \mathrm{mmol} / \mathrm{mol}$ was added to the ratios measured by $A A$.

31. The weak correlation between $\mathrm{Mg} / \mathrm{Ca}$ and $\mathrm{VPI}$ suggests that dissolution may have a minor effect on the $\mathrm{Mg} / \mathrm{Ca}$ ratio of Krithe shells. However, because of the nature of the water masses influencing this site, dissolution is likely to covary inversely with temperature. Thus the weak correlation observed may simply be a residual temperature signal. Furthermore, the full range of $\mathrm{Mg} / \mathrm{Ca}$ values occurs at the intermediate VPI value of 4 . The lack of a significant correlation between Krithe Sr/Ca ratios and the VPI of Site 607 ostracode samples, as well as the high and nearly constant down-hole values of Krithe $\mathrm{Sr} / \mathrm{Ca}$ ratios, indicate that burial diagenesis (recrystallization) is not an important factor in these samples. Recrystallization of biogenic calcites in deep-sea sediments typically leads to a fourfold decrease in the original $\mathrm{Sr} /$ $\mathrm{Ca}$ ratios over a period of $10^{7}$ years $(46)$

32. J. Imbrie et al., Paleoceanography 7, 701 (1992).

33. T. M. Cronin, Quat. Sci. Rev. 10, 175 (1991)

34. H. J. Dowsett and T. M. Cronin, Geology 18, 435 (1990).

35. L. D. Keigwin and G. A. Jones, J. Geophys. Res. 99, 12397 (1994).

36. D. C. McCorkle et al., Paleoceanography 5, 161 (1990).

37. N. J. Shackleton and N. D. Opdyke, Quat. Res. 3, 39 (1973)

38. T. M. Cronin et al., in preparation

39. T. M. Cronin et al., Palaeogeogr. Palaeoclimatol. Palaeoecol. 108, 437 (1994).

40. R. G. Fairbanks, Nature 342, 637 (1989). Some of the calculated $\delta^{18} \mathrm{O}_{\mathrm{sw}}$ values in late Quaternary stage 2 and in the deglaciation between stages 2 and 1 are much higher than expected and yield sealevel estimates that are markedly different from previously accepted values. If we assume that our temperature estimates are accurate, this may be due to one or both of the following factors: (i) non-ice volume-related changes in $\delta^{18} \mathrm{O}_{\text {sw }}$ at this site or (ii) interpolation of the benthic foraminiferal $\delta^{18} \mathrm{O}$ recordthere are only two benthic foraminiferal $\delta^{18} \mathrm{O}$ data points spanning the time interval where the largest discrepancies occur.

41. T. M. Cronin and G. S. Dwyer, unpublished data.

42. S. Rahmstorf, Nature 372, 82 (1994); T. Fichefet, S. Hovine, J.-C. Duplessy, ibid., p. 252.

43. T. M. Cronin, in The Last Three Million Years: Evolution of Climatic Variability in the North Atlantic Region, N. J. Shackleton et al., Eds. (Royal Society, London, 1988), pp. 661-678.

44. __ and H. J. Dowsett, in Environmental and Biotic Changes in the Neogene of Central America, J. B. C. Jackson et al., Eds. (Univ. of Chicago Press, Chicago, in press)

45. G. P. Coles, R. C. Whatley, A. Moguilevsky, Palaeontology, 37, 71 (1994)

46. P. A. Baker, J. M. Gieskes, H. Elderfield, J. Sediment. Petrol. 52, 71 (1982).

47. F. C. Fuglister, Atlantic Ocean Atlas (Woods Hole Oceanographic Instititute, Woods Hole, MA, 1960).

48. H. Craig and L. I. Gordon, in Stable Isotopes in Oceanographic Studies and Paleotemperatures (Consiglio Nazionale delle Richerche Laboratorio di Geologia Nucleare, Pisa, Italy, 1965), pp. 9-130.

49. S. C. Cande and D. V. Kent, J. Geophys. Res. 97, 13917 (1992).

50. We thank E. Klein for access to the Duke University Department of Geology DCP lab; W. Curry, J. Broda, and P. Mills for sampling the Chain core; E. Boyle and $L$. Keigwin for Chain core sample splits and stable isotope data; $\mathrm{H}$. Dowsett for Pliocene SST data; N. Shackleton and S. Hart for comments; and R. Perkins and M. Malone for helpful suggestions on the text. Financial support for this research was provided to G.S.D., T.M.C., and P.A.B. by the U.S. Geological Survey Global Change Program and by NSF (OPP 9400250). NSF grant 9101734 and Office of Naval Research grant 14-89-J-1034 supported the Seafloor Samples Lab of Woods Hole Oceanographic Institution. NSF grant OCE92-57191 supported the contributions of M.E.R

15 June 1995; accepted 5 September 1995

\title{
Designer Cytokines: Targeting Actions to Cells of Choice
}

\author{
Aris N. Economides, Jeffrey V. Ravetch, \\ George D. Yancopoulos, ${ }^{\star}$ Neil Stahl*
}

Some growth factors are therapeutically useful partly because restricted expression of their receptors limits their action to particular cell types. However, no unique stimulatory factor is known for many clinically relevant cell types, such as CD34 ${ }^{+}$hematopoietic stem cells. Here, soluble $\alpha$ receptor $(\mathrm{R} \alpha)$ components for interleukin-6 (IL-6) and ciliary neurotrophic factor (CNTF) were targeted in an active form to cells expressing surface markers such as CD34 or CD45, thereby rendering those cells responsive to IL-6 or CNTF. The targeting of $R \alpha$ components may provide the means to create "designer" cytokines that activate a desired cell type expressing a specific cell surface marker.

Cytokines and growth factors regulate vital biological processes such as induction and regulation of immune responses, cellular proliferation, differentiation, and apoptosis and are of potential use in the treatment of human diseases (1). Proteins such as erythropoietin, granulocyte colony-stimulating factor, and thrombopoietin are therapeutically promising at least in part because restricted expression of their receptors limits their sites of action. However, many other cytokines, such as leukemia inhibitory factor (LIF), have not proven to be useful therapeutically because of their pleiotropic effects resulting from the widespread expression of their receptors $(2,3)$. LIF induces the differentiation of myeloid M1 cells, activates the proliferation of DA1.1 myeloid cells, increases the number of megakaryocyte progenitors in vivo, inhibits differentiation of embryonic stem (ES) cells, activates the cholinergic switch of sympathetic neurons, and promotes bone remodeling. Although some of the actions of LIF would be therapeutically desirable, others are deleterious; mice injected with cells secreting large amounts of LIF die after 2 to 10 weeks (4). However, if the action of LIF could be restricted to new bone formation $(4,5)$, inhibition of adipogenesis (6), or stimulation of $\mathrm{CD} 34^{+}$hematopoietic stem cells (7), this more specific cytokine could have therapeutic value.

CNTF, a member of the cytokine family that encompasses LIF, IL-6, oncostatin M, IL-11, and cardiotrophin- $1(8,9)$, is in a sense a cell-specific counterpart to LIF. The action of CNTF is more restricted because unlike LIF, the receptor for which consists solely of the signal-transducing components LIFR and gp130 $(10,11)$, CNTF addition-

A. N. Economides, G. D. Yancopoulos, N. Stahl, Regen eron Pharmaceuticals, 777 Old Saw Mill River Road, Tarnytown, NY 10591, USA.

J. V. Ravetch, Laboratory of Biochemical Genetics, Sloan Kettering Institute, 1275 York Avenue, New York, NY 10021, USA.

*To whom correspondence should be addressed. ally requires a specificity-determining $\mathrm{R} \alpha$ component termed CNTFR $\alpha$ to which it must bind before interacting with gp130 and LIFR $(12,13)$. Thus, although both CNTF and LIF induce heterodimerization of the signal transducers gp130 and LIFR and lead to identical downstream signal transduction events, the sites of CNTF action are restricted to cells that express CNTFR $\alpha$ in addition to gp130 and LIFR (14). CNTFR $\alpha$, which is anchored to the cell membrane by a glycosyl-phosphatidylinositol linkage, does not appear to participate directly in transducing the signal (15). Similar to CNTF, both IL-6 (16) and IL-11 (17) require a specificity-determining $R \alpha$ component (IL-6R $\alpha$ and IL-11R $\alpha$, respectively); the complex of $R \alpha$ and cytokine initiates signal transduction by inducing gp130 to homodimerize $(13,18)$. Thus, in general terms, these three $R \alpha$ components function as required specificity components for their cognate cytokines (Fig. 1A).

We report here a way to exploit these $R \alpha$ components to create new, specific cellular targets for CNTF or IL-6. We achieved this by targeting soluble $\operatorname{R} \alpha(\mathrm{sR} \alpha)$ components to the surface of any cell expressing the common signal-transducing receptor components gp130 and LIFR. R $\alpha$ targeting relies on a unique feature of the $\mathrm{R} \alpha$ components: $\mathrm{Al}$ though the soluble extracellular domains of most receptors function as antagonists (19, 20), soluble CNTFR $\alpha$ (sCNTFR) and IL-6R $\alpha$ (sIL-6R) function agonistically by binding their cognate cytokine and then interacting with their signal-transducing components on the cell surface $(15,21)$. Thus, LIF-responsive cells that express gp130 and LIFR, but not CNTFR $\alpha$, become CNTF-responsive in the presence of sCNTFR. Similar to LIF, the combination of CNTF and sCNTFR is not cellselective; high concentrations (up to $2.5 \mu \mathrm{g}$ / $\mathrm{ml}$ ) of $\mathrm{sR} \alpha$ must be used because it is not concentrated on the cell surface. In contrast, addition of a cell surface binding domain to an $s R \alpha$, such as a monoclonal antibody, should 